\title{
Pharmacy cost outliers in primary care; multilevel approach based on ACG in the Spanish context
}

A Prados, D Bordonaba, A Sicras, J Estelrich, M Aza, D Bordonaba, A Calderón, MS Corbacho, F González, MJ Lallana, A López-Cabañas, J Magdalena, B Oliván, B Poblador* and A Poncel

Address: Avda. Gómez Laguna 25, planta 11, Zaragoza, 50009, Spain

Email: B Poblador* - bpoblador.iacs@aragon.es

* Corresponding author

from 24th Patient Classification Systems International (PCSI) Working Conference Lisbon, Portugal. 8-II October 2008

Published: 27 November 2008

BMC Health Services Research 2008, 8(SuppI I):AI8 doi:I0.II86/I472-6963-8-SI-AI8

This abstract is available from: http://www.biomedcentral.com/I472-6963/8/SI/AI8

(c) 2008 Prados et al; licensee BioMed Central Ltd.

\section{Introduction}

The objective of this study was to analyse variability in pharmacy cost in Primary Care through a multilevel approach including patient, physician and health centre organisation variables. The analysis was carried out separately for normal and outlier patients concerning pharmacy expenditure.

\section{Methods}

Multicentre, retrospective study based on electronic records of patients seeking care during 2005 in the regions of Aragón, Baleares and Cataluña. Principal measurements: variables related to the patient (age, sex and morbidity), the health centre (accreditation, teaching activities and localization - rural/urban centre), the physician (academic training, sex and work-experience) and the dependent variable pharmacy cost. In order to avoid data collection biases, health centres were selected depending on their experience in the use of electronic medical records. Outlier patients were identified according to case-mix adjustment-based statistic criteria (those with values of studentized deleted residuals higher than

Table I: Multilevel regression models for normal users.

\begin{tabular}{|c|c|c|c|c|c|}
\hline Normal users & & & & & \\
\hline Pharmacy cost (In) & & MODEL I & MODEL II & MODEL III & MODEL IV \\
\hline \multicolumn{6}{|l|}{ Patient } \\
\hline & Age & & & & $0.040(0.000)$ \\
\hline & Sex & & & $0.08(0.000)$ & \\
\hline & ACG & $0.05(0.000)$ & $0.05(0.000)$ & $0.05(0.000)$ & $0.033(0.000)$ \\
\hline \multicolumn{6}{|l|}{ Physician } \\
\hline & Sex & & $-0.28(0.000)$ & $-0.28(0.000)$ & $0.04(0.183)$ \\
\hline & Academic training & & $-0.30(0.002)$ & $-0.30(0.000)$ & $0.15(0.000)$ \\
\hline & Work experience & & $-0.01(0.015)$ & $-0.01(0.001)$ & $0.01(0.000)$ \\
\hline & $\mathbf{R}^{2}$ & 0.313 & 0.317 & 0.317 & 0.488 \\
\hline & $\sigma_{\mathrm{e}}$ & 1.470 & 1.470 & 1.470 & 1.307 \\
\hline & $\sigma_{\mathrm{v}}$ & 0.554 & 0.533 & 0.403 & 0.222 \\
\hline & $\rho$ & 0.124 & 0.1161 & 0.070 & 0.028 \\
\hline
\end{tabular}


Table 2: Multilevel regression models for outlier patients.

\begin{tabular}{|c|c|c|c|c|c|}
\hline Outliers & & & & & \\
\hline Pharmacy cost (In) & & MODEL I & MODEL II & MODEL III & MODEL IV \\
\hline \multicolumn{6}{|l|}{ Patient } \\
\hline & Age & & & & $-0.01(0.000)$ \\
\hline & Sex & & & $-0.03(0.059)$ & \\
\hline & ACG & $0.04(0.000)$ & $0.04(0.000)$ & $0.04(0.000)$ & $0.04(0.000)$ \\
\hline \multicolumn{6}{|l|}{ Physician } \\
\hline & Sex & & $-0.02(0.278)$ & $-0.02(0.296)$ & $-0.02(0.146)$ \\
\hline & Academic training & & $0.02(0.402)$ & $0.02(0.389)$ & $0.02(0.384)$ \\
\hline & Work experience & & $0.01(0.060)$ & $0.01(0.051)$ & $0.01(0.036)$ \\
\hline & $\mathbf{R}^{2}$ & 0.611 & 0.602 & 0.602 & 0.603 \\
\hline & $\sigma_{\mathrm{e}}$ & 0.518 & 0.518 & 0.518 & 0.518 \\
\hline & $\sigma_{v}$ & 0.021 & 0.064 & 0.064 & 0.044 \\
\hline & $\rho$ & 0.002 & 0.015 & 0.015 & 0.007 \\
\hline
\end{tabular}

2). Log transformation of the variable pharmacy cost was carried out to reduce skewness of the distribution and make it close to normal. The explanatory power of ACG was calculated by coefficients of determination. Multilevel regression models were employed to analyse the hierarchical structure of data (level 1: patient, level 2: physicians, level 3: health centre). Statistical software: SPSS 15.0, STATA SE/10.0, MLWin 2.0, $\mathrm{p}<0.01$.

\section{Results}

Outlier patients represent $1.6 \%$ of the global population ( $n=286,450)$ and are responsible for $10.87 \%$ of the total pharmacy cost in Primary Care. Among the three different included levels, the one related to the health centre was insignificant either for normal or outlier patients. The results for the two other levels - patient and physician are shown in Tables 1 and 2. Among normal users, up to $12.4 \%$ of the total variance in pharmacy cost was explained by variables inherent to physician; whereas, among outlier patients, the explanatory power of this second level (physician) was negligible $(0.2 \%-1.5 \%)$. For normal users, the model that best explained variability in pharmacy cost included patient's variables (ACG and age) and physician's variables (academic training and work experience) $\left(\mathrm{R}^{2}=48.8 \%\right)$.

\section{Conclusion}

- Variability in pharmacy cost is explained mainly by the patient's characteristics of morbidity (measured by ACG).

- Physicians seem to have a lower influence on outlier patients, defined as those with no clinical reasons for higher costs, than on normal users. This could be attributed to the fact that this "spendthrift habit" of patients is more difficult to be influenced by physicians, whose decision-making capacity is therefore reduced.
- The fact that the third level (health centre organization) was not significant could be due to the characteristics of the selected health centers, all of them located in an urban area and experienced in the use of electronic medical records.

Further investigation should be done on other factors related to the physician and the specific clinical aspects of patients (e.g. severity, co-morbidity) influencing uncommonly high cost trends in Primary Care since outliers are a legitimate economic concern to individual practitioners, institutions and policy makers.

\begin{tabular}{|} 
Publish with Biomed Central and every \\
scientist can read your work free of charge \\
"BioMed Central will be the most significant development for \\
disseminating the results of biomedical research in our lifetime." \\
Sir Paul Nurse, Cancer Research UK \\
Your research papers will be: \\
- available free of charge to the entire biomedical community \\
- peer reviewed and published immediately upon acceptance \\
• cited in PubMed and archived on PubMed Central \\
• yours - you keep the copyright \\
Submit your manuscript here: \\
http://www.biomedcentral.com/info/publishing_adv.asp
\end{tabular}

